\title{
MOTIVATIONAL STRATEGIES USED BY AN ENGLSH TEACHER AT HAND FORTUNA CENTER
}

\author{
Maria Priskila Rohi ${ }^{1}$, Samuel Gunawan ${ }^{2}$ \\ English Department, Faculty of Letters, Petra Christian University \\ Surabaya, East Java, Indonesia \\ E-mail: ryscar22@gmail.com, samgun@petra.ac.id
}

\begin{abstract}
This is a qualitative study on the use of motivational strategies by the English teacher at Hand Fortuna Center. This study was based on Dörnyei's (2001) theory about motivational strategies and focused on the interaction between the teacher and his students in the classroom. The data were collected by using video recording and interview. The observation was done in three meetings within two weeks. The duration of the class was 90 minutes for each meeting. The findings showed that the teacher used five out of eight motivational strategies in the classroom. There were making learning stimulating and enjoyable, protecting the learners' self-esteem and increase their self-confidence, presenting task in a motivating way, allowing learners to maintain a positive social image, and promoting cooperation among the learners. For the interview, the writer found that the reason why the teacher used the motivational strategies. It was because the strategies could increase students' motivation in learning language.
\end{abstract}

Key words: Motivational Strategies, Classroom Interaction, Maintaining and Protecting Students' Motivation.

\section{INTRODUCTION}

Interaction between teacher and students are a part of language learning process. Teachers are seen as the role model to guide and inspire students to learn in class. Therefore, a teacher has big responsibility to make the students be motivated in learning language while having interaction with students. The reason is because "everything a teacher does in the classroom has a motivational influence on students" (Dörnyei, 2001, p. 32).

In this study, the writer focused on strategies that the teacher used to motivate students in learning language named motivational strategies. The writer observed the teaching and learning process in an English course and focus on the motivational strategies used by the teacher and students in a Youth Class which is only taught by one teacher. The course is located in Kupang named Hand Fortuna Center.

The reason why the writer chose to observe the high school students was inspired by a statement of Light and Spada (2006) which showed that many teenagers lack of motivation to get involved in academic activities such as learning a new language. Therefore, many researcher and educator made studies focusing on how to increase teenagers' motivation in learning language.

In this study, the Youth Class was chosen to be observed because of some reasons. First, the teacher named Mr. Sumartono gave best practices in teaching English. Second, after the writer did her observation in the first week, she saw that the students made many interactions with the teacher. They expressed their opinion directly about the activity or asked the teacher about what they did not understand about the material. Third, the task or activity was various so as to make the class more fun.

To see the motivational strategies used by the teacher, the writer used the theory by Dörnyei (2001) about motivational strategies in the language classroom. Basically, each aspect has some motivational components. In this study, the writer did not focus on all the motivational aspects. The writer only focused on maintaining and protecting motivation because this aspect is used as the support to maintain students' motivation in learning English, protect the students' desire to learn English, and make activities more interesting to the students (Dörnyei, 2001).

In doing the research, the writer had two objectives to achieve. First, the writer wanted to find out the types of motivational strategies used by the teacher in maintaining and protecting 
students' motivation in the Youth Class of Hand Fortuna Center. Second, the writer wanted to know about the reasons on the choice of strategy being used in the classroom.

The writer observed the class and recorded the class meeting. The process of collecting the data was done for two weeks in September 2016. The data of this research was collected by using video recorder during 90 minutes in each meeting. The writer collected the data in three times of meeting. The writer also conducted an interview with the teacher to get additional information of motivational strategies used by the teacher. Since this study was only restricted to three class meetings with duration of 90 minutes, therefore, the whole appearance of motivational strategies tend to be minimal.

Hopefully, this study provides insightful knowledge to teachers with regards to motivate students. Besides, the finding and discussion could help the teachers how to maintain and protect students' interest in learning English. Also, teachers may be able to reflect their teaching of using motivational strategies in the classroom. Therefore, teachers can increase their understanding about the appropriate strategies in motivation their students to learn and love English.

\section{METHODS}

The sources of this study were all interactions between the teacher and the students taking place in the classroom during the lesson and the interview which was conducted with the teacher. The data was collected by using video recorder. For the interview, the writer recorded direct responses from the teacher by using audio recorder. The questions of the interview were semistructured from theory by Dörnyei (2001). The writer did the interview in English with the teacher. The subject of the writer's observation was the English teacher in an English course. The duration of each of the two meetings was 90 minutes within the same week. The class consisted of one male and eight female students.

The writer used video recording to record the interactions between teacher and students during 90 minutes teaching and learning process in each meeting. The class was recorded three times on September 20th, 22th, and 27th, 2016. The writer did three interviews after the teacher finished his teaching activities in the classroom.

After the writer finished the recording, she started to transcribe the data of the first, second, and third meetings. Each utterance and/or action was given a code number. The coding was as follows: for example 1.2, 2.1, 3.3, etc. This means that the first digit refers to the class meeting, whereas the second digit refers to the order of the appearance of the data in the class meeting. These transcripts were found in the appendices 1,2 , and 3 .

In analyzing the data, the writer did several steps. First, the writer summarized the theory to help her in analyzing the data to determine the characteristics of motivational strategies. Second, after making the characteristics of the theory, the writer looked at all utterances and actions one by one in the transcript and the writer used the characteristics of the theory as her guideline. When motivational strategies were found, the writer gave a bold in the transcript. Third, after making the data in the transcript with the bold and coding number, the writer put all the utterances and actions one by one in the table analysis. The writer also used notes from her opinion about the analysis. The analysis was made in description form. After that, the writer explained one by one of the teacher's utterances and actions to answer her research questions.

Table 3.2 Table of Analysis

\begin{tabular}{|c|c|c|c|c|}
\hline \multicolumn{3}{|c|}{$\begin{array}{l}\text { Name of course: } \\
\text { Class time: } \\
\text { Class length: }\end{array}$} & \multicolumn{2}{|c|}{$\begin{array}{l}\text { Name of teacher: } \\
\text { Total number of students: }\end{array}$} \\
\hline $\begin{array}{l}\text { Code } \\
\text { Number }\end{array}$ & $\begin{array}{l}\text { Teacher's utterances and } \\
\text { actions }\end{array}$ & $\begin{array}{c}\text { Characteristics of } \\
\text { motivational strategies }\end{array}$ & $\begin{array}{c}\text { Types of } \\
\text { motivational } \\
\text { strategies }\end{array}$ & Notes \\
\hline & & & & \\
\hline & & & & \\
\hline
\end{tabular}


After the writer analyzed the motivational strategies used in the classroom, the writer put the specific data from the interview into the second table 3.3 to help the writer answer the research questions. The questions of the interview were divided on the basis of the eight motivational strategies related in maintaining and protecting students' motivation which have sub-strategies.

\section{ANALYSIS AND FINDINGS}

There are eight motivational strategies in maintaining and protecting students' motivation. There were three motivational strategies that were not used by the teacher in the classroom. They were setting specific learner goals, creating learner autonomy, and promoting self-motivating learner strategies.

The reason why the strategy in setting specific learner goals did not appear because the teacher did not use goal-setting method in class like giving short-term goals to do as homework. The teacher did not use contracting methods with students like making an agreement together about the specific rules. The other strategy, creating learner autonomy did not appear because the teacher held the main role in organizing the learning process. The last strategy which the teacher did not use was promoting self-motivating learner strategies. The reason was during the three meetings, the teacher did not talk about the importance of self-motivation in class. Therefore, these three strategies did not appear during the three meetings in the classroom observation.

There were five strategies applied by the teacher in the teaching and learning processes. Based on the order of frequency of occurrences the type from the teaching observed were presented as follows:

Making Learning Stimulating and Enjoyable: To make the learning process more stimulating and enjoyable, motivational strategies were needed.

\section{- Breaking the monotony of learning}

In the middle of the second meeting, Mr. Sumartono showed a video. Then, he explained the content of the video to the students. In this example, the teacher prepared a video to support his teaching. After he explained about many things about Africa, he showed the real life in Africa based on the video. He paused one by one of the video and told the students about what happened in Africa. He also gave a comparison by giving example about the real life in Indonesia. This made the students understand more about the topic that they discussed in class besides the teacher's explanation. It showed that the teacher was successful to make the class more relax and enjoyable.

In the beginning of the class in the first and the second meeting, Mr. Sumartono asked the students to do something before they started the learning process. Before he started the teaching and learning process, Mr. Sumartono asked the students to greet each other in classroom. This made the class more convenient to start with a warmer action which can stimulate the students' desire in learning the language.

In the third meeting, the teacher asked students to play a game. It was a game for the students to deliver a short speech in two minutes based on the question from the teacher. He gave a game based on the topic that they would discuss in class. He asked the students one by one to deliver a short speech. Then, students stood in front of the class and the teacher gave a question which he had already prepared for the students about the topic. This showed that the teacher gave motivation to his students through the game, so students felt relaxed in doing the activities in the classroom.

In the second meeting, the teacher played two music videos after he gave the activity. He asked students to sing the song together. After the class finished, the teacher prepared a laptop and LCD to play two music videos which were the topic they had discussed in class. When the teacher asked the student to sing together, the writer saw that the students felt surprised. This showed that motivation could come from how the teacher made something to make sure the students feel relaxed and happy while learning process took place.

\section{- Making the tasks more interesting}

In the third meeting, Mr. Sumartono gave a challenging task for students to do in the classroom. He asked students to search problems which happened in NTT based on the topic in class. He asked the students to do the activity individually not in group. When the students did the activity, 
they used their gadget to search information in internet about the problems in NTT (Nusa Tenggara Timur). Therefore, they felt more convenient to do the activity.

In the first meeting, the teacher gave an interesting topic to discuss in class. The content of the tasks attracted the students' desire to do it. In the second meeting, Mr. Sumartono talked a special topic to discuss in class. The teacher gave a topic which is new and totally unexpected for students. The content of the topic helped to eliminate boredom in class. By doing that, the teacher was successful to make the students enjoy in the learning process and increase students' knowledge about something new in their life.

\section{- Increasing students involvement}

In the first meeting, Mr. Sumartono made an activity for students to do in a group. Besides that, in the third meeting, the teacher gave an activity for students to do individually. After the teacher explained about what students should make to do the activity, he divided students in a group. They should discuss the problems in a group. This was illustrated as the class discussion which made students to be interesting. The criteria of the example showed that the teacher selected a task which requires mental involvement from each student. They made a discussion with their friends in group and shared their opinion one by one. Therefore, all students are able to understand what they should do in group. Besides that, the teacher also asked students to do the activity individually. When they finished the activity, each student came in front of the class and presented their result very well.

In the third meeting, Mr. Sumartono created a specific role for each student in doing the activity. The example above showed that the teacher prepared an activity to give chance for every student to be active in class. He asked students to pretend as a regent from NTT. The writer could see during her observation that the teacher asked each student to choose their regency, they answered it very excited. In that situation, each student looked active to do the activity.

Protecting the Learners' Self-Esteem and Increasing Their Self-Confidence: Dörnyei (2001) proposes that there are four strategies for protecting the learners' self-esteem and increasing their self-confidence: provide experiences of success, encourage them, reduce language anxiety, and teach learner strategies.

\section{- Providing experiences of success}

In the three meetings, Mr. Sumartono gave a new topic and tasks that made students excited to do the tasks. The non-verbal actions was done by the teacher to prepare a new topic and tasks for students, then it increased their motivation to learn and solve something new in the learning process. Students also got some new experiences in their learning process because they knew how to solve problems in carrying out the activities.

\section{- Encouraging the learner}

In the first meeting, Mr. Sumartono gave words of praise to students after they presented their answer. He also asked other students to repeat the words in unison by also mentioning the names of the students who presented in front of the class. From the example above, it showed that the teacher believed in students' effort to complete the activity. Through his word, other students would feel motivated to present well their answer.

In the second meeting, Mr. Sumartono showed his attention to a student who did something wrong in grammar. The student who presented the answer was a child with special needs. Although he acted like that, he had a good confident to speak English in front of the class. When he finished his presentation, the teacher tried to give motivation through his word. He did it because he trusted the student ability in learning. On the other side, students also feel more confident if someone believes in their abilities than they feel alone in the learning process.

\section{- Reducing language anxiety}

In the first and the second meeting, Mr. Sumartono made an activity which involved students to discuss in group. The example showed that the teacher promote cooperation among students by doing the activity as group. He divided the group in three and asked them to discuss together. When they finished the discussion, he asked each group to come in front of the class and asked them to 
speak their answer one by one. He did it because he wanted every student could speak up and delivered their own opinion well.

In the second meeting, there was a student who said inappropriate word to say when she gave her answer about Africa. Then, Mr. Sumartono made correction of the student's utterance about the word. When the student made a mistake, the teacher gave a correction directly. He noticed that the students should not use the word to describe someone. Then, he told to other students how to use good word when describe someone.

\section{- Teaching learner strategies}

In the first meeting, Mr. Sumartono gave an example for students how to do presentation in front of the class. In the example, it could be seen that the teacher gave a good example to students how they should present their presentation in front of the class. When students did the presentation, they followed what the teacher said and did well. It was motivated and increased their confident to participate in $\mathrm{L} 2$ task.

Presenting Task in a Motivating Way: To present the task properly, Dörnyei (2001) recommended that teachers should explain the purpose and utility of a task, whet the students' appetite about the content of the task, and provide appropriate strategies to do the task.

\section{- Explaining the purpose and the utility of a task}

In the second meeting, Mr. Sumartono explained the task to students about what they should do. Before the teacher asked students to do the activity, he explained every part in detail. It made students more understand and know what they should do.

\section{- Whetting the students' appetite}

To the writer's observation, Mr. Sumartono always show his enthusiasm when he introduced the class activities. The teacher showed his enthusiasm to students that the activity would be fun to do in class. From the three examples, the teacher made an interesting way before he talked about the activity. During the writer's observation, she saw that the teacher's expression when introduced the activity was happy and excited. He showed his smile and his voice which showed that he enthusiastically to introduce the activity.

\section{- Providing appropriate strategies to do the task}

In the first meeting, Mr. Sumartono gave an example before he asked students to do the task. In the third meeting, he did the same thing. He gave an example then he asked students to do the activity.

The two examples showed that Mr. Sumartono introduced the activity by preparing it very well. Before he asked students to do the activity, he gave example from him to make students understand. It could be seen when the teacher gave example, students knew how to do and answer it.

Allowing Learners to Maintain a Positive Social Image: This component is used to protect students' motivation in learning language.

In the third meeting, Mr. Sumartono made a role for students to do the activity. The example showed that the teacher create a good roles for students to participate in the activity.

Promoting Cooperation among the Learners: This strategy is used to increase students' cooperation in the learning process. Students can learn together through peers or team work.

In the first meeting and the second meeting, Mr. Sumartono divided students in a group to discuss a topic. The examples above showed that the teacher selected an activity in which students are asked to work together towards the same goal. When students are asked to do the activity, they have same goal to achieve in find out the answer and delivered their opinion in group.

Now, this is the explanation about the reasons for the choice and application particular motivational strategies in the classroom. The writer only gives brief explanation of each strategy that used in the classroom. 
First, in the making the learning stimulating and enjoyable, the teacher said that he always give a sense of teaching, sense of love, and sense of humor for students. In this part, the teacher made some activities or tasks to make students feel relax, make the atmosphere more fun in the class, and increase students' desire in the learning language.

The second strategy is protecting the learners' self-esteem and increases their selfconfidence. In this part, the teacher gave some activities to maintain students' confidence in the classroom. For example, he asked students to demonstrate the task; the teacher tried to provide experience of success. It could improve students' confidence in speaking. He also encourages the learner by giving his praise for students through his words. Then, he made some cooperation tasks among students to make students can work in team. Finally, he prepared and taught strategies to make students more confident in front of the class.

The third strategy is presenting tasks in a motivating way. This strategy is used to make students feel motivate to do the tasks in class. In this part, the teacher increase students' desire in doing the tasks by giving some explanation the purpose of the task to students and demonstrate the tasks for the students to make them understand about what they should do.

The fourth strategy is allowing learners to maintain a positive social image. This is the reason why the teacher made activities that required the students to play 'good' roles. The teacher gave several tasks or activities to do in the class by asking them to pretend as someone who has a good role to make it more fun for students.

The last strategy is promoting cooperation among learners. This reason is used to make a task which can be worked in a team. In this part, the teacher asked students to do the tasks or activities in a group. In the group, every student would make discussion and deliver their own opinion and they will achieve the same goal in discussing the topic.

Overall, the writer has concluded that there is indeed a several reason why the teacher used those five strategies in the classroom. First, the teacher wants to make his students feel fun and relax in doing the tasks or activities. Second, the teacher wants to improve students' confidence when they did presentation or come in front of the class. Third, the teacher wants to make understand about what they should do in doing the tasks or activities. Fourth, the teacher prepares 'good' roles to pretend as someone in doing the activity. Last, the teacher makes students can work in a team to achieve the same goals.

\section{CONCLUSION}

The findings showed that five out of eight motivational strategies occurred in three observed class meeting. The frequency of the occurrences of the types from teaching observed showed that making learning stimulating and enjoyable placed on the high stage. It was because the teacher used this strategy in the whole meetings. The second was protecting the learners' self-esteem and increase their self-confidence. This strategy was used to provide experience of success, encourage learn, reduce their language anxiety, and teach learner strategies. The third strategy was presenting tasks in a motivating way. In this strategy, the teacher gave motivation to students through some tasks in classroom. The fourth strategy was allowing learners to maintain a positive social image. The teacher used this strategy by doing a good role for the students in the classroom. The last strategy was promoting cooperation among the learners. This strategy was used to make students work in a group. Through all those motivational strategies used by the teacher, the students got motivated in learning English in the classroom. For the interview showed the teacher's reasons in using the motivational strategies were to make the class more fun, make students active and participate in every activity, and gives students chance to express their idea or opinion.

\section{REFERENCES}

Brophy, J. (2004). Motivating Students to Learn ( $2^{\text {nd }}$ ed.). London: Lawrence Erlbaum Associates. Cheng, H. and Dörnyei, Z. (2007). The Use of Motivational Strategies in Language Instruction: The Case of EFL Teaching in Taiwan. Retrieved April 27 th 2016 from http://www.zoltandornyei.co.uk/uploads/2007-cheng-dornyei-illt.pdf

Dörnyei, Z. (2001). Motivational Strategies in the Language Classroom. New York: Cambridge University Press. 
Dörnyei, Z. (2007). Research Methods in Applied Linguistics: Quantitative, Qualitativ, and Mixed Methodologies. Oxford: University Press.

Lightbown, M. P. and Spada, N. (2006). How Languages are Learnerd ( ${ }^{\text {rd }}$ ed.). Oxford: Oxford University Press

Long, C., Ming, Z., \& Chen, L. (2013). The Study of Student Motivation on English Learning in Junior Middle School -- A Case Study of No.5 Middle School in Gejiu. Journal of English Language Teaching. 6(9), 136-145 Retrieved from http://dx.doi.org/10.5539/elt.v6n9p136

Marzano, J. R., Pickering, J. D., \& Heflebower, T. (2010). The Highly Engaged Classroom. Retrieved December $16^{\text {th }}, 2016$ from http://www.centergrove.k12.in.us/cms/lib4/IN01000850/Centricity/Domain/1217/The\%20Mai n\%20Idea\%20-\%20The\%20Highly\%20Engaged\%20Classroom.Pdf

Palmer, D. (2005). A Motivational View of Constructivist-informed Teaching. International Journal of Science Education, 27(15), 1853-1881.

Orio, S.F. (2013). Motivation and Second Language Acquisition. Retrieved December 16 ${ }^{\text {th }}, 2016$ from http://biblioteca.unirioja.es/tfe_e/TFE000342.pdf

Rudhumbu, N. (2014). Motivational Strategies in the Teaching of Primary School Mathematics in Zimbabwe. International Journal Education and Development UK, 2(2), 76-103.

Yousevin. (2015). Motivational Strategies Applied in the First Grade of Primary School. Retrieved from Digital Collection Petra Christian University 